\title{
Hemşirelerde Danışmanlık Becerileri Ölçeği'ni (HDBÖ) Geliştirilmesi: Geçerlik ve Güvenirlik Çalışması
}

\author{
Illknur AYDIN AVCI,Hatice KUMCAĞIZ*
}

\author{
Hemşirelerde Danışmanlık Becerileri Ölçeği'nin (HDBÖ) \\ Geliştirilmesi: Geçerlik ve Güvenirlik Çalışması
}

\section{Özet}

Bu çalışmada hemşirelerin danışmanlık becerilerini ölçebilecek geçerlik ve güvenirlikte bir ölçme aracı geliştirmek amaçlanmıştır. Ölçek için oluşturulan madde havuzuna son şekli verildikten sonra açımlayıcı faktör analizi için 204 hemşireye uygulama yapılmıştır. Ölçeğin tek faktörden ve 10 maddeden oluştuğu görülmüştür. Sonrasında 200 hemşire ile Doğrulayıcı Faktör Analizi (DFA) yapılmıştır. DFA ile tek faktörlü yapının uyum indeksi değerlerinin kabul edilebilir sınırlar içerisinde olduğu görülmüştür $(\chi 2=94.785, \mathrm{sd}=33, \chi 2 / \mathrm{sd}=2.872, \mathrm{RMSEA}=0.097, \mathrm{GFI}=0.92$, $A G F I=0.86, C F I=0.92$ ve IFI=0.92). Ölçeğin geçerliği $A F A$ ve $D F A$ yapılmak suretiyle incelenmiştir. Ölçeğin güvenilirliği ise Cronbach alfa katsayısı ve Split-half ile incelenmiştir. Cronbach alfa .88, Split-half ise 86 olarak hesaplanmıştır. Elde edilen sonuçlara göre HDBÖ’nin hemşirelerin danışmanlık becerilerini belirlemek amacıyla kullanılabileceğini göstermiştir.

Anahtar Kelimeler: Hemşire, Danışmanlık, Danışmanlık Becerisi, Ölçek Geliştirme.
Developing Counseling in Nurses Scale: Validity and Reliability Study

\section{Abstract}

The purpose of the study was to develop a valid and reliable scale for the assessment of the counseling skills of nurses. After the final version of the item pool was generalized, it was administered to 204 nurses for exploratory factor analysis. The scale was found to consist of one factor and 10 items. Confirmatory factor analysis was then held with 200 nurses. The fit index between the confirmatory factor analysis and one-factor structure had acceptable values $(\chi 2=94.785, \quad s d=33, \chi 2 / s d=2.872, \quad R M S E A=0.097$, $\mathrm{GFI}=0.92, \mathrm{AGFI}=0.86, \mathrm{CF}=0.92$ and $\mid \mathrm{FI}=0.92$ ). The validity of the scale was examined with exploratory and confirmatory factor analysis. The reliability of the scale was confirmed with Cronbach Alpha and Split-half. Cronbach Alpha was measured as .88, and Split-half was found to be .86 . According to the results, it was shown that the scale could be used to determine the counseling skills of nurses.

Key Words: Nurse, Counseling, Counseling Skill, Developing Scale.

\section{Giriş}

Bilim ve teknolojideki hızlı gelişmeler bireylerin ve toplumların yaşam biçimleri ile yaşamdan beklentilerini tümüyle değiştirmiştir. Bu gelişmeler hemşirelerin mesleki rollerinde de değişikliklere neden olmuştur. Birtakım direktifler alan geleneksel hemşirelik modeli yerine, eleştirel düşünen, derinlemesine sorgulayan hemşirelik modeli benimsenmeye baş-

\footnotetext{
* illknur AYDIN AVCI, Prof.Dr., Ondokuz Mayıs Üniversitesi, Sağıık Bilimleri Fakültesi, Halk Sağlığı Hemşireliği Anabilim Dalı, e-posta: ilknura@omu.edu.tr, ORCID ID orcid.org /0000-0002-5379-3038, Hatice KUMCAĞIZ, Doç.Dr., Ondokuz Mayıs Üniversitesi, Eğitim Fakültesi Eğitim Bilimleri Bölümü, Rehberlik ve Psikolojik Danışmanlık Anabilim Dalı, e-posta: haticek@omu.edu.tr, ORCID ID orcid.org / 0000-0002-0165-3535
} 
Ilknur AYDIN AVCI | Hatice KUMCAĞIZ

lanmıştır. Bu değişimin sonucu olarak da hemşireler hasta bakımında bağımsız olarak hemşirelik rollerini yürütür hale gelmişlerdir (Taylan 2009, s. 34). Hastaları tedavi edici uygulamalar ile tanı ve tedavi işlemlerine yardım etme gibi hekim direktifini içeren uygulamalar, hemşirenin bağımlı olduğu rollerden bazılarıdır (Hatipoğlu, Avcı ve Öztürk, 1996, s. 38). Hemşirelerin bağımsız rolleri, hemşirelerin mesleki bilgi, beceri ve deneyimleri ile çözebileceği hemşirelik bakımı sorunlarını kapsamaktadır (Birol, 1997; Erdal, 1993). Birey hastalanmadan önce sağlığının güçlendirmesine yönelik etkinlikler, hasta bireyin sağlığına kavuşabilmesi için ise gerekli yardımın ve desteğin sağlanması hemşirelerin önemli görevlerindendir. Hemşirelerin destekleyici yaklaşımları hasta bireylerin bağımsız hareket edebilmelerini sağlayarak yaşam kalitelerini artırmaya yönelik davranışlar sergilemelerine, sağlıkı bireylerin de yaşamlarını sağlıklı bir şekilde sürdürebilmelerinde önemli bir etkendir (Birol, 1997; Çakırcalı, 2000).

Hemşirelik, bireylerin, ailelerin ve toplumun beden, zihin ve ruh sağlığını geliştirmek ile ilgili çalışmaları içeren sanat ve bilimdir (Alano, 2002, s. 1). İnsanda sıklıkla görülen çaresizlik, yorgunluk, ağrı, sevinç gibi gereksinimler hemşirenin dikkatini çekebilmektedir. İnsanın varlığının devamlılığının sağlanabilmesinde temel gereksinimlerin karşılanıyor olması gerekmektedir (Paterson ve Zderad, 2008). Danışmanlık ilişkisinde hemşire sıklıkla tetikleyici olarak davrandığı için danışmanlığın başlatılması önemlidir. En iyi sonuçlara ulaşabilmek için hasta ile yapılan görüşmelerde hastanın kendini ifade etmesi yönünde cesaretlendirilmelidir. Görüşmelerin başlangııında hastaya soru sorması ve oturum sürecine katııımı için fırsatlar verilmelidir (Kettunen vd., 2001). Diğer bireylere faydalı olmak isteyen bir kişinin mesleki yeterlik algısının da yüksek olması son derece önemlidir (Kumcağız, Demir ve Karadaş, 2017). Bu bağlamda hastayla sessizliği paylaşmak, hastada olumlu pekiştireç kullanmak, açık uçlu sorular sorarak kendini ifade etmesini sağlamak, duygularıı anladığını belirtmek, konuşulanları özetleyerek yanlış anlaşıımaları önlemek için geri bildirim vermek hemşirenin hastaları ile iletişimlerinde kullandığı terapötik teknikler arasında yer almaktadır (Üstün, Akgün ve Partlak, 2005; Özcan, 2006). Hastaların etkili tedavisi için yalnızca özel bir sağlık profesyoneli değil, sağılık personellerinin iş birliği içinde olması gerekmektedir. Hemşireler yaptıkları işin doğası gereği yılın 365 günü 24 saat hastalarına bakım vermekte olduklarından hastalarının durumlarını daha yoğun anlayabilme fırsatına sahiptirler. Aynı zamanda hasta bakımının sürekliliği sağlanarak hasta bakımında başarılı olma şansı da artmaktadır. Ancak, hasta bakımının etkili olması için sağlık çalışanlarının ekip olarak çalışması gerekmektedir. Hastanın gereksinimlerinin belirlenmesi ve uygun müdahale yaklaşımlarının değerlendirilmesi fizyolojik olarak hastaya ne olduğunun anlaşılmasına, hastaya bakım verenlerin hastaya mümkün olduğunca olumlu yanıt vermesine dayanmaktadır (Mayer vd., 2005). 
Literatür incelendiğinde tedaviyi uygulama gibi bağımlı rollerinin yanısıra bakım verme, eğitim, araştırma, yönetim, karar verme, savunma rolü, kariyer geliştirme, özerk ve sorumluluk sahibi olma, iletişim ve eşgüdüm sağlayıcı, rehabilite edici, konfor sağlayıcı-rahatlatıcı rolü, tedavi edici ve danışman rolü şeklinde güncel hemşirelik rollerinin sıralandığı görülmektedir (Ay vd., 2008; Tosun, 2002, s. 236; Erdemir, 1998, s. 60). Bu çalışmada hemşirenin danışmanlık rolü çerçevesinde danışmanlık becerileri üzerinde yoğunlaşmak amaçlanmaktadır. Hemşirenin iletişimci ve eğitimci rolleriyle bütünleşmiş bir şekilde ortaya çıkan hemşirenin danışmanlık rolü, hemşirenin bağımsız işlevlerindendir (Taylan,2009 s. 60 ). Hemşire, danışmanlık rolü kapsamında hasta/sağlıklı bireyin sağlığını koruma ve geliştirme, yaşam kalitesini artırma, hastalığa bağlı sorunları ile etkili baş edebilme ile ilgili kendi ve etrafındaki olanakları tanıma ve kullanabilme konusunda danışmanlık becerilerini kullanmaktadır (Erdemir, 1988, s. 60).

Danışmanlık 20. yüzyılın başlarında Amerika'da bilim olarak ortaya çıkmıştır. Savaştan sonra gelişen bu süreçte Amerika'da sanayileşmeye geçiş döneminde hayırseverlik çalışmaları, yaşı bakım evleri, sosyal sorunları önlemek amacıyla eğitim faaliyetleri, gazilerin rehabilitasyonu ve istihdam bulmak gibi birçok reform başlatılmıştır (Corey, 2005). Danışmanlık, bir insanın, daha başarılı bir şekilde yaşama yollarını daha iyi bir şekilde keşfetmesine ve açıklığa kavuşturmasına yardımcı olma niyetiyle bir kişinin başka bir kişiye yeterli zaman ayırarak ilgi, dikkat ve saygı gösterdiği bir etkileşim süreci şeklinde tanımlanmaktadır (Palmer vd., 1996, s. 22). Danışmanlık kavramı çeşitli alanlarda kullanılmaktadır; işyeri danışmanlığı, akademik süreçte öğrencilerin gelişimine katkıda bulunmak için akademik danışmanlık, hemşirelerin bağımsız işlevlerinden olan danışmanlık uygulamaları gibi. Bu çaış̧mada hemşirelerin danışmanlık rolünden bahsedilecektir. Danışmanlık, genellikle sağlık sorunları olan kişilere yardımın verildiği etkileşimli bir süreç olarak kabul edilmektedir. Hemşireler hastalara hizmet verdikleri süreçte danışmanlık rolünü de üstlenmektedirler (Kotrotsiou vd., 2014).

Temel danışmanlık becerileri; etkin dinleme, içtenlik ve dürüstlük, kendiliğindenlik, savunmacı olmama, tutarlılık, pozitif kabul ve saygı, anlık olma ve kendini açma, somutluk, yol açıcı tepkiler, içerik tepkileri, duygu tepkileri, özetleme, empati ve yüzleştirme şeklinde özetlenebilir. Bu koşullar danışma süreci boyunca danışman tarafından gerekli olduğunda uygulanmalı ve danışanın bunu görmesi, yaşaması ve hissetmesine özen gösterilmelidir (Nelson-Jones, 2013; Savcı, Demir, Kutlu ve Aysan, 2018). Tüm bu açıklamalardan danışma becerilerinin temelde insan ilişkileri ve iletişim becerilerine dayandığı görülmektedir (ikiz, 2006, s. 35; Demir, Atli ve Kis, 2016). Danışmanlık becerileri kavramını özellikle ruh sağlığı hemşireliği uygulamaları içinde yer almaktadır. Hemşire danışmanlık becerileri sayesinde hastayı yaşadığı sorunlarını inceleme ve bu konularda farkındalık ve anlayış geliştirmeye teşvik etmektedir. Hastanın sorunları değerlendirilerek sağlık ve refaha ulaşabilmek için gerekli olan koşulları ve bu koşulların nasıl başarılabileceğine dair farkındalık yaratmaya 
Illknur AYDIN AVCI | Hatice KUMCAĞIZ

teşvik edilmektedir. Hemşirelik, bireye krizle baş etmede veya yaşam travmalarıla baş etmede yardımcı olmayı amaçlayan kişilerarası bir süreçtir. Hemşirelik uygulamaları yalnızca hastaya bakım ve tedaviyi içermez, aynı zamanda dinleme, anlama ve uygun tepki vermeyi de kapsamaktadır (Freshwater, 2003, s. 6). İlgili alanyazın incelendiğinde Türkiye'de hemşirelerine danışmanlık becerilerine ilişkin çalışmaya ulaşılamamıştır. Ancak, yurt dışında hemşirelerin danışmanlık rolü ile sınırlı sayıda da olsa çalışmalara ulaşılabilmiştir (Kotrotsiou vd., 2008; Digan, 2016). Ayrıca, bu konu ile ilgili geliştirilmiş bir ölçek çalışmasına rastlanılmamıştır. Oysa, danışmanlık becerilerinde önemli bir unsur olan hemşirelerin iletişim becerileri (Kumcağız vd., 2011; Tiryaci-Şen vd., 2013), iletişim ve empati becerileri (ŞahinAkgün ve Özdemir- Kardaş, 2015; Eskici vd., 2016; Tutuk, Al ve Doğan, 2002) ile ilgili çeşitli çalışmaların yapıldığı görülmüştür. Yukarıda açıklanan nedenler bu çalışmanın planlanmasında belirleyici olmuştur. Bu çalışmada, hemşirelerin danışmanlık becerileri ölçeği geliştirilmesi ve geçerlik güvenirlik çalışması yapılması amaçlanmıştır. HDBÖ’nün hemşirelerin danışmanlık becerilerini ölçmeye yönelik bir ölçek geliştirmek planlanmıştır. Ölçeğin özellikle hasta bakım uygulamalarında, hemşirelerin danışmanlık becerilerine ilişkin tutumlarının değerlendirilmesinde önemli bir araç olabileceği düşünülmektedir. Ayrıca hemşirelerde danışmanlık becerilerine ilişkin bir ölçme aracının geliştirmesi, hemşirelerin bu becerileri ile diğer ilişkisel faktörlerin incelenebilmesi için diğer araştırmalara fırsat sunacaktır. Bu bağlamda düşünüldüğünde bu araştırmanın ileriki araştırmalara ve araştırmacılara ışık tutacağı söylenebilir.

\section{Yöntem}

\section{1. Çalışma Grubu}

Bu çalışma, 2018 yılında Samsun ilinde çeşitli hastanelerde hemşire olarak görev yapmakta olan 404 katılımcı ile gerçekleştirilmiştir. Katılımcıların \%71.8'i ( $n=290)$ kadın, $\% 28.2^{\prime}$ si ( $n=114$ ) ise erkektir. Katılımcıların yaşları 19-62 arasında değişmektedir ve yaş ortalamaları ise 30.76 'dır (Ss:7.57). Katılımcıların \%23.5'i lise $(n=95), \% 63.9^{\prime}$ u lisans $(n=258)$ ve $\% 12.6$ 'sı $(n=51)$ ise lisansüstü eğitim mezunudur. Ayrıca katılımcıların \%48.8'i $(n=197)$ evli, \%51.2'si (n=207) ise bekârdır.

\section{2. İşlem}

Çalışmanın gerçekleştirilmesi için öncelikle Ondokuzmayıs Üniversitesi Sosyal Bilimler Etik Kurulu (Karar no: 2018/229)'ndan etik izin, sonrasında ise araştırmanın yapılacağı kurumlardan izin alınmıştır. Katılımcılar araştırma ile ilgili bilgilendirilerek sözlü onamları alınmış ve gönüllü olan hemşireler çalışma kapsamına alınmıştır. Çalışmada öncelikle literatür taraması yapılarak taslak maddeler oluşturulmuştur (Alona, 2002; Corey, 2005; Digan, 2014; Freshwater, 2003). Oluşturulan literatür taramasından sonra araştırmacılar tarafından 75 madde içeren bir soru havuzu oluşturulmuştur. Daha sonra Hemşirelerde Danış- 
manlık Becerileri Ölçeği (HDBÖ)'ni oluşturan maddelerin konu ile uygunluğu ve dil açısından değerlendirilmesi amacıyla psikiyatri hemşireliği, kadın hastalıkları ve doğum hemşireliği, iç hastalıkları hemşireliği ve halk sağlığı hemşireliği alanında olan dört öğretim üyesi, rehberlik ve psikolojik danışmanlık alanında uzman altı öğretim üyesi ve ölçme ve değerlendirme alanında uzman iki öğretim üyesi olmak üzere toplam 12 uzmandan ölçek ile ilgili görüşler alınmıştır. Bu süreçte uzman görüşleri doğrultusunda soruların anlaşılırlığı ve geçerliliği test edilerek madde sayısı 43'e düşürülmüştür. Uzmanlardan gelen değerlendirmeler sonrasında ölçeğe son şekli verilerek ölçme aracının ilk formu hazırlanmıştır. Hazırlanan form 204 hemşireye uygulanmıştır. Elde edilen verilerle açımlayıcı faktör analizi (AFA) yapılmıştır. AFA sonucu ölçeğin 10 maddeden ve tek faktörlü bir yapıdan oluştuğu gözlenmiştir. Sonrasında bu ölçme aracı ikinci bir çalışma grubu olan 200 hemşireye uygulanmıştır. Ölçeğin geçerliği AFA ve DFA ile; güvenirliği ise Cronbach alfa ve Split-half ile test edilmiştir. Bu araştırmada veriler SPSS 21 ve AMOS paket programları aracılığı ile analiz edilmiştir. Ölçme aracında yer alan maddeler 5'li Likert tipi derecelendirme ile yapılmıştır. Her bir madde için "Her zaman (5)", "Çoğu zaman (4)", "Bazen (3)", "Çok Seyrek (2)", "Hiçbir zaman (1)" seçenekleri sunulmuştur. Ölçekten alınan puanlar 10 ile 50 arasında değişmektedir.

\section{Bulgular}

\subsection{Geçerlik Çalışması}

Bu araştırmada geçerlik çalışması kapsamında öncelikle hemşirelerde kullanılması sonucunda nasıl bir yapıda olacağının keşfedilmesi amacıyla açımlayıcı faktör analizi yapıımıştır. Sonrasında ölçeğin oluşan faktör yapısının uyumunu incelemek maksadıyla ikinci bir çaış̧ma grubunda doğrulayıcı faktör analizi yapıımıştır. Açımlayıcı faktör analizi (AFA) yapıyı anlama, doğrulayıcı faktör analizi (DFA) de bu yapıyı test etmeye yönelik yapılmaktadır ve aynı örneklem grubundan hem AFA hem de DFA'nın yapılması uygun bulunmamaktadır (Erkuş, 2012).

\subsubsection{Yapı geçerliliği}

3.1.1.2. Açımlayıcı faktör analizi: Hemşirelerde Danışmanlık Becerileri Ölçeği (HDBÖ)'nin açımlayıcı faktör analizi 204 hemşireden toplanan veriler vasıtasıyla yapılmıştır. Illk olarak toplanan verilerin faktör analizi için uygun olup olmadığı Kaiser-Meyer-Olkin (KMO) katsayısına bakılması suretiyle incelenmiş ve örneklem uygunluk katsayısının .88 olduğu görülmüştür. Bu sonuca göre toplanan verilerin açımlayıc faktör analizi yapmak için yeterli olduğu ifade edilebilir (Çokluk, Şekercioğlu ve Büyüköztürk, 2014). Hemşirelerde yapılan açımlayıcı faktör analizinde yapılan ilk işlem sonucunda, öz değeri 1'in üzerinde olan 9 faktör olduğu ve bu 9 faktörün toplam varyansın \%60.78'ini açıkladığı görülmektedir; ancak AFA sonrasında binişik ve bitişik maddeler ile madde faktör yük değeri .30'un altında olan ölçek maddelerinin olduğu görülmüş ve bu maddeler çıkartılarak ve analiz tekrar gerçekleştirilmiştir. Açımlayıcı faktör analizi kullanılarak temel bileşenler analizi ile herhangi 
bir döndürme yapılmadan gerçekleştirilen analizler sonucunda, ölçeğin özdeğeri 1'in üzerinde olan tek faktörlü bir yapıda olduğu görülmüştür. Başlangıçta 43 olan madde sayısı bitişik, binişik ve faktör yük değerleri .30'un altında olan maddeler çıkarıldıktan sonra 10'a düşmüştür. 10 maddeden ve tek faktörlü olan bu yapının özdeğerinin 4.8 olduğu ve toplam varyansın \% 48.41'ini açıkladığı bulgusuna ulaşılmışır (Bakınız Şekil 1). HDBÖ'nün ikinci faktörünün özdeğerinin 0.84 , üçüncü faktörünün .82 olduğu diğer faktörlerin ise $.70^{\prime}$ in altında olduğu görülmüştür. Diğer bir ifadeyle ilk faktörden sonraki faktörlerin özdeğerleri 1'den küçüktür ve bunun sonucunda da diğer faktörler ayrı ayrı boyut olarak değerlendirilmemiştir.

Şekil 1. HDBÖ’ye İlişkin Yamaç Birikinti Grafiği

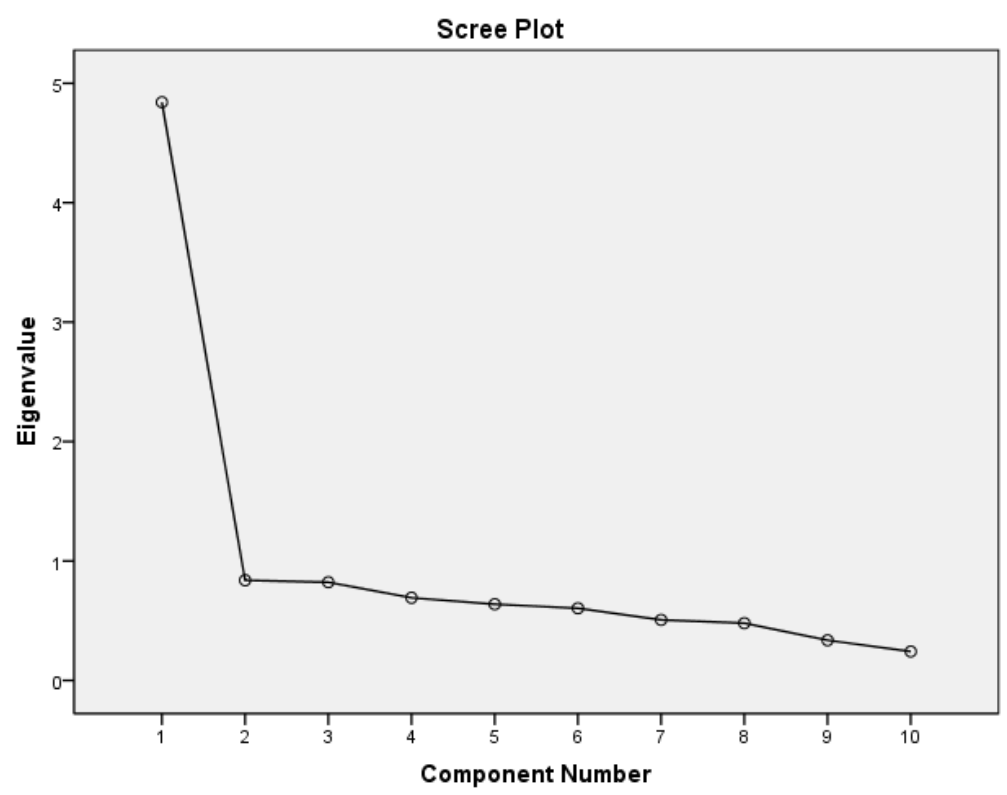


Ölçek maddelerinin faktör yük değeri Tablo 1'de verilmiştir.

Tablo 1. HDBÖ'nün Açımlayıcı Faktör Analizi Sonrasındaki Faktör Yük Değerleri

Madde

Faktör

Yükü

1. Hastaları ayırt etmeden onlara saygılı davranırım.

.68

2. Hastaların ifade ettikleri sorunları dinlerim.

.77

3. Hastaların bakım süreçlerine iliş̧in gelişmeleri takip ederim.

4. Hastalara ait kişisel bilgileri özenle saklarım.

.70

5. Hastalarla ilişkilerimde özgüvenli olduğumu hissettiririm.

.64

6. Hastalara yardım ederken tecrübeli olan bireylerden faydalanıım. $\quad .65$

7. Hastaları sorunlarının çözümü konusunda inançlı olmaları için mo- $\quad .67$

tive ederim.

8. Hastalarla ilişkilerimde sakinimdir.

9. Hastalar, her yönüyle onları kabul ettiğimi anlar.

.69

10. Hastalar ile güler yüzlü ve sıcak bir ilişki kurarım.

.70

3.1.1.3. Doğrulayıcı faktör analizi: Açımlayııı faktör analizi sonucunda tek faktörlü olarak ortaya çıkan HDBÖ'nün bu yapısı farklı bir çalışma grubunda doğrulayııı faktör analizi yapılması suretiyle test edilmiştir. Hemşirelerde DFA yapmak için 200 (145 kadın, 55 erkek) hemşireden toplanan veriler kullanılmıştır. DFA yapıldıktan sonra uyum indeksi degerleri $\chi 2=158.108, s d=35, \chi 2 / s d=4.517, R M S E A=0.133, G F I=0.87, A G F I=0.79, C F I=0.84$ ve $\mathrm{IFI}=0.84$ olarak bulunmuştur. Bu değerlerin kabul edilebilir sınırların altında olduğu görülmüş ve önerilen modifikasyonlar incelenmiştir. İki adet modifikasyon yapıldığında modelin kabul edilebilir uyum indeksi değerlerine sahip olduğu görülmüştür $(\chi 2=94.785, \mathrm{sd}=33$, $\chi 2 / \mathrm{sd}=2.872, \mathrm{RMSEA}=0.097, \mathrm{GFI}=0.92, \mathrm{AGFI}=0.86, \mathrm{CFI}=0.92$ ve $\mathrm{IFI}=0.92)$. HDBÖ'ye ilişkin Standardize Edilmiş Yol Katsayıları Şekil 2'de verilmiştir. 
Şekil 2. HDBÖ’ye ilişkin Standardize Edilmiş Yol Katsayıları

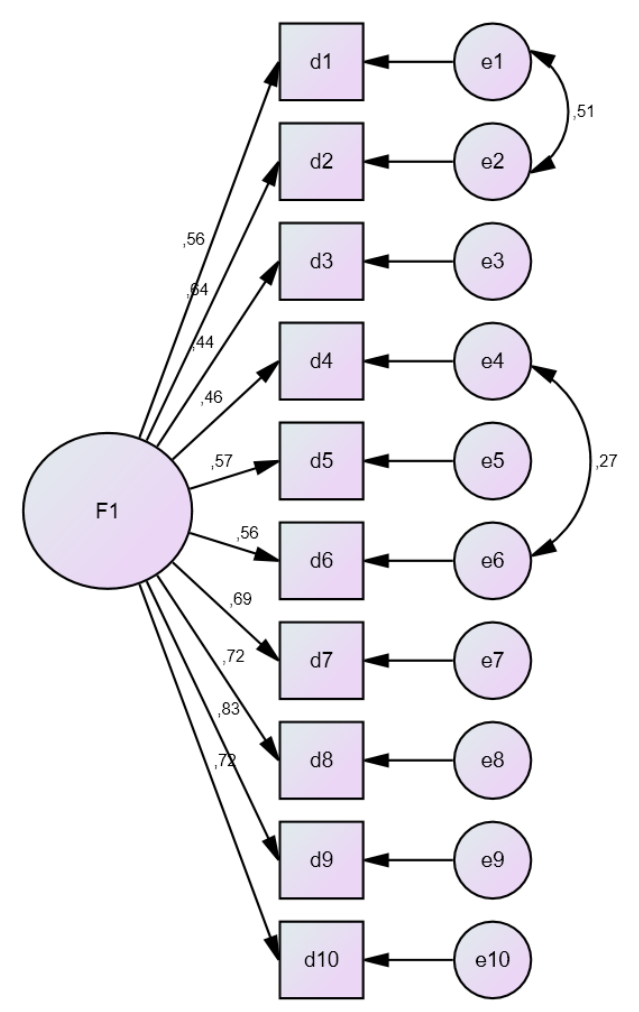

\subsection{Güvenirlik}

Bu çalışmanın güvenirliği iç tutarlık ve iki yarım test güvenirliği olmak üzere iki şekilde incelenmiştir. Cronbach alfa iç tutarlık güvenilirlik katsayısının .88, Split-half iki yarım test güvenirlik katsayısının ise .86 olarak hesaplandığı görülmüştür. Bu sonuçlar ölçme aracının güvenilir olduğunun bir göstergesi olarak kabul edilebilir (Durmuş, Yurtkoru ve Çinko; 2013).

\section{Tartışma, Sonuç ve Öneriler}

Günümüzde danışmanlık becerileri hemşirelerin hastalar ile iletişimlerinde önemli rol oynamaktadır. Her ne kadar kanser ve palyatif bakım, stoma bakımı, jinekoloji ve nöroloji gibi uzmanlık özel uzmanlık alanlarında çalışan farklı sağlık çalışanları olsa da koşullar ne olursa olsun hemen hemen her hemşire-hasta etkileşiminde danışmanlık becerileri yaygın 
olarak kullanılmaktadır (Freshwater, 2003). Hemşire danışmanlık becerileri sayesinde hasta ya da ailesine hastalık ile ilgili farkındalık kazanmalarını sağlayarak, yaşadıkları süreci öğrenmeleri, sorunları ile ilgili baş edebilmede etkili kaynakları kullanmaya teşvik etme ve bilimsel bilgiye ulaşabilme konularında destek olmaktadır (Gedük-Aydemir, 2018, s. 256). Hemşire almış olduğu eğitim ve sahip olduğu klinik tecrübelere dayanarak sahip olduğu danışmanlık becerileri ile hasta/hasta yakınının fiziksel, duygusal ve sosyal iyilik durumunun yeniden düzenlemeye yönelik uygulamaları gerçekleştirmeyi amaçlamaktadır.

Bu çalışman amacı hemşirelerde danışmanlık becerileri ölçeği (HDBÖ) geliştirmektedir. Bu amaç doğrultusunda literatür taranmak suretiyle madde havuzu oluşturulmuş ve uzman görüşü alındıktan sonra açımlayıcı faktör analizi (AFA) yapmak suretiyle alanda çalışan hemşirelere ulaşılmıştır. Literatürde KMO testi örneklem yeterliliği ölçütü, gözlenen korelasyon katsayıları büyüklüğü ile kısmi korelasyon katsayılarının büyüklüğünü karşılaştırmak için kullanıldığı belirtilmektedir (Büyüköztürk, 2011). Veri setinin faktör analizine mükemmel uyum yapabilmesi için KMO değerinin .90'a yakın bir değer olması gerektiği belirtilmektedir (Kalaycı, 2006; Büyüköztürk, 2011). Bunun yanısıra Barlett's hipotez testi ile uygunluk istatistiksel yönden değerlendirilmelidir (Büyüköztürk, 2011). Çalışmada HDBÖ'ne uygulanan Barlett's testi sonucuna göre elde edilen verilerin faktör analizi için mükemmel düzeyde uyumlu olduğu sonucuna ulaşılmıştır (KMO: .88; $p=.00 ;<\alpha=.01$ ). Elde edilen bulguların HDBÖ’nnin hemşirelerin danışmanlık becerilerinin ölçülmesine olanak sağlayabileceği düşündürmektedir. AFA sonucunda hemşirelerde özdeğeri 4.8 olan ve toplam varyansın \%48.41'ini açıklayan bir yapıda olduğu görülmüştür. Eğer ölçek tek faktörden oluşuyorsa toplam faktörün \%30'unu açıklamasının yeterli olduğu vurgulanmaktadır (Büyüköztürk, 2011; Çokluk vd. 2014). AFA'ya ilişkin faktör yükleri incelendiğinde ölçeğin faktör yüklerinin .64 ile .77 arasında olduğu gözlenmiştir. DFA'da ki uyum indeksi değerlerinin $(\chi 2 / \mathrm{sd}=2.872, \mathrm{RMSEA}=0.097, \mathrm{GFI}=0.92, \mathrm{AGFI}=0.86, \mathrm{CFI}=0.92$ ve $\mathrm{IFI}=0.92)$ de kabul edilebilir sınırlar içerisinde olduğu görülmektedir (Çokluk vd., 2014; Şimşek, 2007; Tavşancıl, 2006). Bu sonuçlar birlikte değerlendirildiğinde HMDB'nün danışmanlık becerilerini ölçmek için geçerli bir ölçme aracı olduğu söylenebilir. Bu araştırmada HDBÖ’nin güvenirlik analizi sonuçlarına göre Cronbach Alfa değeri .88 bulunmuştur. Split-half ise .86 olarak hesaplanmış ve bu hesaplamalar sonucunda da ölçek güvenilir bulunmuştur. Literatürde Cronbach Alpha değerlerinin .70'in üzerinde olması güvenirlik için yeterli olduğu kabul edilmektedir (Bayram, 2004).

Çalışmada, 10 maddeden oluşan HDBÖ’nin danışmanlık becerilerini değerlendirmede geçerli ve güvenilir bir şekilde ölçtüğü sonucuna ulaşılmıştır. Bu çalışmadan elde edilen bulgulara dayanarak HDBÖ’nin güvenilirliğinin zamana göre değişmezliğini değerlendirmek için aynı gruba test-tekrar test çalışması yapılması, hemşirelerin danışmanlık becerilerini değerlendirmek üzere geçerlik güvenilirliği yapılmış benzer bir ölçekle birlikte eşzamanlı olarak kullanılarak güvenilirliğini yeniden test edecek çalışmalar yapılması önerilmektedir. Ayrıca, HDBÖ’nin daha geniş örneklemde ve/veya farklı kültürel özelliklerdeki toplumlarda 
Illknur AYDIN AVCI | Hatice KUMCAĞIZ

bakım veren hemşireler açısından yeniden geçerlik ve güvenilirliğinin değerlendirilmesi ölçeğin gelişmesine katkı sağlayabileceği düşünülmektedir.

\section{Kaynaklar}

Akgün-Şahin, Z., ve Özdemir-Kardaş, F. (2015). Hemşirelerin İletişim ve Empati Beceri Düzeylerinin Belirlenmesi. JAREN/Hemşirelik Akademik Araştırma Dergisi, 1(1), 1-7.

Alona, A. (2002). Basic Clinical Nursing Skills. Awassa: Ethiopia Public Health Training Initiative.

Ay, F., Ertem, Ü., Özcan, N., Ören, B., Işık, R. ve Sarvan, S. (2007). Temel hemşirelik kavramlar, ilkeler, uygulamalar. İstanbul: Nobel Tıp Kitapevi.

Bayram, N. (2004), Sosyal bilimlerde spss ile veri analizi. Bursa: Ezgi Kitabevi.

Birol L. (1997). Hemşirelik Süreci (4. Baskı). İzmir: Etki Matbaaclık.

Büyüköztürk, Ş. (2011). Sosyal bilimler için veri analizi el kitabı. Ankara: Pegem Akademi.

Corey, G. (2005). Theory and Practice of Counseling and Psychotherapy. Athens: Ellin Publications.

Çakırcalı E. (2000). Hasta Bakımı ve Tedavisinde Temel illke ve Uygulamalar. (3. Baskı). İzmir: Güven Kitabevi.

Çokluk, Ö., Şekercioğlu, G., \& Büyüköztürk, Ş. (2014). Sosyal bilimler için çok değişkenli istatistik: SPSS ve LISREL uygulamaları. Ankara: Pegem Akademi.

Demir, Y., Atli, A., \& Kis, A. (2016). Empathy Based on Gender in Dissertations Submitted in Turkey: A Meta-Analysis Study. Eurasian Journal of Educational Research, 64, 69-90.

Digan, J. (2014). Are the Counselling Skills Nurses Learn in Training Apparent in Their Everyday Interactions with Patients and Carers?. Unpublished Doctorate thesis. faculty of Humanities University of Manchester.

Durmuş, B., Yurtkoru, E. S., Çinko, M. (2013). Sosyal Bilimlerde Spss'le Veri Analizi, (5.Baskı). İstanbul: Beta Yayınclık.

Erdal E. (1993). Hemşirelikte Temel İlke ve Uygulamalar. İzmir: Ege Üniversitesi Basımevi.

Erdemir F. (1998). Hemşirenin Rol ve İşlevleri ve Hemşirelik Eğitiminin Felsefesi. C.Ü. Hemşirelik Yüksekokulu Dergisi, 2(1), 59-62.

Erkuş, A. (2012). Psikolojide Ölçme ve Ölçek Geliştirme. Ankara: Pegem Akademi Yayınları.

Eskici, V., Gümüş, K., Yayla, A., Özlü, İ., Aksoy, A., Yeşilay, Y. (2016). Acil Birimlerde Çalışan Hemşirelerin Iletişim Becerileri Ve Empati Düzeylerinin Değerlendirilmesi. Uluslararası Hakemli Hemşirelik Araştırmaları Dergisi, 8, 52-71. 
Freshwater, D. (2003). Counselling Skills for Nurses, Midwives and Health Visitors. Philadelphia: Open University Press.

Gedük-Aydemir, E. (2018). Hemşirelik Mesleğinin Gelişen Rolleri. Sağlık Bilimleri ve Meslekleri Dergisi, 5 (2):253-258.

Hatipoğlu i., Avcı Y. ve Öztürk A. (1996). Hemşirelik Esasları. (2. Baskı). Ankara: Damla Matbaacılık.

ikiz, F. E. (2006). Danışma becerileri Eğitiminin Danışmanların Empatik Eğilim, Empatik Beceri ve Tükenmişlik Düzeyleri Üzerine Etkisi. Yayımlanmamış Doktora Tezi. Dokuz Eylül Üniversitesi Eğitim Bilimleri Anabilim Dalı Psikolojik Danışma ve Rehberlik Programı, İzmir.

Kalaycı S. (2006). SPSS uygulamalı çok değişkenli istatistiksel teknikleri. Ankara: Asil Publication Distribution.

Kettunen, T.N., Poskiparta, M. ve Liimatainen, D. (2001). Empowering Counselling-A Case Study: Nurse-Patient Encounter in a Hospital. Health Education Research, 16, 227-238.

Kotrotsiou, E., Gouva, M., Kotrotsiou, S., Malliarou, M., \& Paralikas, T. (2014). Validation of the Greek Translation of the Nursing Dimensions Inventory questionnaire (NDI-35). Global journal of health science, 6(5), 30.

Kotrotsiou, E., Gouva, M., Kotrotsiou, S., Malliarou, M., \& Paralikas, T. (2014). Validation of the Greek

Kotrotsiou, S., Lavdaniti, M., Psychogiou, M., Paralikas, T.H., Papathanasiou, I. ve Lahana, E. (2014). Community Nurses' Role as Counsellors in Primary Health Care. International Journal of Caring Sciences, 1(2), 92-98.

Kumcağız, H., Demir, Y. ve Karadaş, C. (2017). Okul Psikolojik Danışmanlarında Mesleki Tükenmişliğin Yordayıcısı Olarak Özel Eğitime ilişkin Öz-yeterlik Algısı. Inönü Üniversitesi Eğitim Fakültesi Dergisi, 18(3), 312-324.

Kumcağız, H., Yılmaz, M., Çelik, Balcı-Çelik, S. ve Avcı-Aydın, i. (2011). Hemşirelerin iletişim becerileri: Samsun ili örneği. Dicle Tıp Dergisi, 38 (1), 49-56.

Mayer, C., Andrusyszyn. M. A. ve Iwasiw, C. (2005). Goodman Award Paper: Self-efficacy of Staff Nurses for Health Promotion Counselling of Patients at Risk for Stroke. Axone, 26, 14-21.

Nelson-Jones, R. (2013). Temel Psikolojik Danışma Becerileri. (Çev.Gamze Sart). Ankara: Nobel Yayınevi.

Özcan, A. (2006). Hemşire Hasta Illişkisi ve Illetişim. 2. Basım. Ankara: Sistem Ofset Yayıncılık.

Paterson, J. G., Zderad, L. (2008). Humanistic Nursing. Bebook. Www.Gutenberg.Org/Files/25020/25020-8.Txt. 
İlknur AYDIN AVCI | Hatice KUMCAĞIZ

Savci, M., Demir, . Y., Kutlu, . M. ve Aysan, . F. (2018). Theoretical Orientation of Mental Health Workers in Turkey. Journal of Cognitive-Behavioral Psychotherapy and Research, 7 (2), 72-79. doi:10.5455/JCBPR.278015

Şencan H. (2005). Sosyal ve Davranışsal Ölçümlerde Güvenirlik ve Geçerlik. Ankara: Seçkin Yayıncilık.

Şimşek, Ö. F. (2007). Yapısal Eşitlik Modellemesine Giriş: Temel Ilkeler ve LISREL Uygulamaları. Ankara: Ekinoks.

Tavşancıl, E. (2006). Tutumların Ölçülmesi ve SPSS ile Veri Analizi. Ankara: Nobel Yayıncılık.

Taylan, S. (2009). Özerklik ilkkesi Çerçevesinde Hemşirenin Bağımsız Rolleri. Yayımlanmamış Yüksek Lisans Tezi. Sağlık Bilimleri Enstitüsü, Adana.

Tiryaci-Şen, H., Yılmaz Taşkın, F. ve Ünüvar-Pekşen, Ö. (2013). Hizmet İçi Eğitim Hemşirelerinin Illetişim Beceri Düzeyleri. Psikiyatri Hemşireliği Dergisi, 4, 13-20.

Tosun N., Akbayrak N. (2002). Sağlık ekibi ve ekibin bir üyesi olarak hemşirenin rolü. Sendrom Dergisi, 14(1), 133-137.

Tutuk, A., Al, D. ve Doğan, S. (2002). Hemşirelik Öğrencilerinin İletişim Becerisi Ve Empati Düzeylerinin Belirlenmesi. C. Ü. Hemşirelik Yüksek Okulu Dergisi, 2002, 6 (2), 36-41.,

Uğur, E. (2010). Yönetici Hemşirelerin Koçluk Becerileri ve Öz-Etkililik-Yeterlilik Algılamaları. Yayımlanmamış Doktora Tezi, Marmara Üniversitesi, Sağlık Bilimleri Enstitüsü, İstanbul.

Üstün, B., Akgün, E. ve Partlak, N. (2005). Hemşirelikte İletişim Becerileri Öğretimi, İzmir: Okullar Yayınevi. 